\title{
Education of making natural hand sanitizers to the community of Haulasi Village, North Central Timor Regency
}

\author{
Risna Erni Yati Adu ${ }^{1 *}$, Didi Prasetyo Benu ${ }^{1}$, Florian M. P. R. Makin ${ }^{1}$, Dicky . Hanas ${ }^{1}$, \\ Ite M. Y. Tnunay ${ }^{1}$, Kamaluddin ${ }^{2}$ \\ ${ }^{1}$ Fakultas Pertanian, Universitas Timor, Kefamenanu, NTT, Indonesia \\ ${ }^{2}$ Fakultas Ilmu Pendidikan, Universitas Timor, Kefamenanu, NTT, Indonesia \\ *Email: risnaadu12@unimor.ac.id
}

\begin{abstract}
The availability of hand sanitizers, which is one of the Covid-19 prevention media, is becoming scarce and expensive due to their increasing use, making them difficult to reach by the public. Therefore we need another source of active ingredients that more easily obtained, available in abundant quantities and more economically to be used as a substtitute for hand sanitizer raw materials by the public. Potential alternantive material to be used as raw material for hand sanitizer is betel leaves, however, public knowledge about the benefits and methods of processing betel leaves into hand sanitizer is very limited. Therefore, education about the use of betel leaves into natural hand sanitizer products to rural communitties needs to be done to increase people's insight about making natural hand sanitizer and increase public awareness in maintaining hygiene by providing and using similar products.
\end{abstract}

Keyword: Hand sanitizer, Betel Leaves, Covid-19

\begin{abstract}
Abstrak
Ketersediaan hand sanitizer yang merupakan salah satu media pencegah Covid-19 menjadi langka dan mahal akibat penggunaannya yang meningkat, menjadikannya sebagai produk yang sulit dijangkau oleh masyarakat. Oleh karena itu dibutuhkan sumber bahan aktif lain yang lebih mudah diperoleh, tersedia dalam jumlah melimpah dan lebih ekonomis untuk digunakan sebagai pengganti bahan baku hand sanitizer oleh masyarakat. Alternatif bahan yang potensial untuk digunakan sebagai bahan baku hand sanitizer adalah daun sirih, meskipun demikian pengetahuan masyarakat tentang kemanfaatan maupun cara pengolahan daun sirih menjadi hand sanitizer sangat terbatas. Oleh karena itu, edukasi tentang pemanfaatan daun sirih menjadi produk hand sanitizer alami kepada masyarakat pedesaan perlu dilakukan untuk meningkatkan wawasan masyarakat tentang pembuatan hand sanitizer alami dan meningkatkan kesadaran masyarakat dalam menjaga kebersihan dengan menyediakan serta menggunakan produk serupa.
\end{abstract}

\section{Kata Kunci: Hand sanitizer, Daun Sirih, Covid-19}

\section{PENDAHULUAN}

Wabah COVID-19 merupakan wabah serius yang sedang dihadapi oleh masyarakat Indonesia. COVID-19 merupakan penyakit menular yang disebabkan oleh virus bernama SARS-COV-2, atau seringkali disebut Virus Corona. Hingga saat ini (25/5/2020) di Indonesia tercatat 22.750 kasus positif dengan jumlah meninggal 1.391(Kompas.com). Di NTT sendiri saat ini tercatat 85 kasus dengan satu orang meninggal (Pos-Kupang.com). Organisasi Kesehatan Dunia (WHO) telah menghimbau berbagai cara pencegahan penyebaran virus corona, diantaranya menjaga jarak dengan orang lain $(1,5 \mathrm{~m})$, menggunakan masker, meningkatkan imunitas tubuh dengan mengkonsumsi makanan sehat, berolahraga serta mencuci tangan. Tindakan mencuci tangan secara teratur menggunakan gel antiseptik yang mengandung alcohol (hand sanitizer), atau rutin mencuci tangan pada air yang mengalir menggunakan sabun merupakan salah satu langkah paling efektif 
dalam mencegah masuknya virus ke dalam tubuh melalui kontak tangan pada hidung, mata dan mulut.

Pencegahan penyebaran virus Corona melalui tindakan mencuci tangan secara teratur menggunakan hand sanitizer menyebabkan penggunaan sediaan gel antiseptik untuk tangan meningkat. Hal ini memicu terjadinya kelangkaan persediaan hand sanitizer yang dibutuhkan oleh masyarakat. Kelangkaan hand sanitizer menjadi penyebab melonjaknya harga dari hand sanitizer itu sendiri maupun harga bahan-bahan baku pembuatan hand sanitizer. Pada akhirnya produk tersebut hanya dapat dijangkau oleh kalangan masyarakat tertentu. Di sisi lain, tindakan preventif terhadap penyebaran virus melalui tindakan mencuci tangan menggunakan hand sanitizer harus tetap dilakukan.

Media pencuci tangan seperti hand sanitizer lebih diminati dibandingkan sabun karena lebih praktis. Pemakaiannya yang efektif dan efisien serta dapat membunuh kuman dalam waktu relatif cepat menjadi daya tarik utama. Pada umumnya bahan aktif dari hand sanitizer merupakan senyawa golongan alkohol dengan konsentrasi $\pm 60 \%$ sampai $80 \%$ dan senyawa golongan fenol (triklosan). Harga bahan-bahan aktif tersebut tergolong mahal tetapi juga dibutuhkan dalam jumlah banyak sehingga menjadi sulit dijangkau oleh masyarakat kalangan bawah. Untuk itu dibutuhkan sumber bahan aktif lain yang lebih mudah diperoleh, tersedia dalam jumlah melimpah dan lebih ekonomis untuk digunakan sebagai bahan baku hand sanitizer. Salah satu sumber alternative bahan aktif yang potensial digunakan sebagai bahan antiseptik adalah tanaman sirih.

Tanaman sirih (Piper bettle L) merupakan jenis tanaman yang tumbuh merambat dengan ketinggian mencapai 5-15 m serta diketahui sangat berkhasiat dalam penyembuhan terhadap penyakit kulit yang disebabkan oleh bakteri karena memiliki daya antiseptik yang baik. Bagian tanaman yang digunakan yaitu bagian daun karena banyak mengandung senyawa turunan fenol. Ekstrak tanaman sirih telah dikembangkan menjadi suatu bentuk sediaan gel antiseptik tangan yang memiliki aktivitas antibakteri yang tidak berbeda bermakna dengan sediaan etanol (untuk kadar ekstrak daun sirih $15 \%$ ), sedangkan sediaan dengan kadar ekstrak 20\% dan 25\% mempunyai aktivitas yang sama dengan sediaan triclosan (Sari dan Isadiartuti, 2006). Ekstrak daun sirih memiliki senyawa antibakteri yang efektif dalam menghambat bakteri seperti Staphylococcus aureus pada konsentrasi 25\% (Bustanussalam dkk., 2015). Meskipun demikian, akses informasi serta pengetahuan masyarakat tentang informasi-informasi bermanfaat tersebut masih terbatas khususnya di wilayah pedesaan. Oleh karena itu perlu dilakukan sosialisasi dan edukasi kepada masyarakat terkait pembuatan hand sanitizer dari bahan sirih yang keberadaannya melimpah di wilayah Kabupaten Timor Tengah Utara sebagai salah satu media dalam pencegahan Covid-19. Pada akhirnya masyarakat menjadi lebih tahu dan terampil dalam menyediakan antiseptik secara mandiri dalam menjaga kebersihan.

\section{METODE PELAKSANAAN}

Pengabdian kepada masyarakat ini bertempat di Desa Haulasi, Kecamatan Miomaffo Barat, Kabupaten Timor Tengah Utara, Provinsi Nusa Tenggara Timur. Untuk pelaksanaannya, berlangsung selama 3 hari, pembuatan hand sanitizer dilakukan pada Selasa, 2 Juni 2020, pemberian label pada produk dilakukan pada Rabu, 3 Juni 2020 sedangkan edukasi cara pembuatan dan pembagian dilaksanakan pada Kamis, 4 Juni 2020.

Kegiatan pengabdian kepada masayarakat ini berupa pembuatan, edukasi cara pembuatan, dan pembagian hand sanitizer dari daun sirih kepada masyarakat di desa Haulasi. Edukasi dan pembagian hand sanitizer dilakukan melalui kunjungan dari rumah ke rumah dengan masingmasing rumah dikunjungi oleh 2 (dua) orang anggota tim pengabdian. Bahan yang digunakan adalah daun sirih, lidah buaya, jeruk nipis, parfum dan air bersih sedangkan alat yang digunakan adalah botol plastik ukuran $100 \mathrm{~mL}$ dan seperangkat alat dokumentasi kegiatan. Prosedur pembuatannya adalah sebagai berikut:

a. $50 \mathrm{gr}$ daun sirih dicuci bersih, dikeringkan, dan dipotong-potong. 
b. Dimasak dengan $100 \mathrm{~mL}$ air bersih sampai mendidih.

c. Ekstraknya disaring dan didinginkan.

d. Lidah buaya secukupnya dimasak sampai matang.

e. Disaring airnya kemudian diblender.

f. Dicampurkan dengan ekstrak daun sirih dan ditambahkan dengan air jeruk nipis dan parfume secukupnya dan dimasukan ke dalam botol $100 \mathrm{~mL}$.

Adapun informasi manfaat bahan penyusun hand sanitizer alami yang dibuat adalah:

a. Daun sirih sebagai bahan aktif anti bakteri.

b. Lidah buaya sebagai bahan pelembab dan pelembut pada tangan saat digunakan.

c. Jeruk nipis untuk menghilangkan aroma khas sirih.

d. Parfum sebagai pewangi.

\section{HASIL DAN PEMBAHASAN}

Kegiatan pengabdian ini secara umum terdiri atas 2 tahapan utama dengan deskripsi sebagai berikut:

\section{a. Pembuatan dan Pemberian Label pada Hand sanitizer}

Kegiatan pengabdian ini diawali dengan penyiapan raw material yang akan digunakan pada pembuatan hand sanitizer seperti daun sirih hijau (Piper betle, L.), lidah buaya (Aloe vera), dan jeruk nipis (Citrus aurantifolia). Sebelum dicampur menjadi cairan hand sanitizer yang homogen, ketiga bahan tersebut diproses melalui beberapa jalur yang berbeda. Daun sirih dicuci kemudian diblender hingga halus untuk mempermudah proses penyarian zat aktif yang terkandung didalamnya. Proses penyarian atau ekstraksi dilakukan menggunakan pelarut air panas melalui metode maserasi. Hasil maserasi difiltrasi untuk memisahkan komponen padatan daun sirih dari ekstraktan. Sedangkan lidah buaya sebagai bahan tambahan pada produk dipisahkan kulit dari dagingnya kemudian direbus lalu dihaluskan. Sari lidah buaya yang telah dihaluskan masih mengandung padatan sehingga dilakukan filtrasi. Lidah buaya sebagai bahan tambahan produk berfungsi sebagai pelembut di tangan saat digunakan. Bahan tambahan lain seperti jeruk berfungsi untuk menghilangkan aroma sirih. Bahan-bahan handsanitizer yang telah tersedia dicampur dengan rasio ekstrak sirih terhadap campuran lidah buaya-jeruk nipis 4:1. Sehingga volume ekstrak sirih $80 \mathrm{ml}$, sedangkan volume campuran lidah buaya-jeruk nipis yang digunakan adalah $20 \mathrm{ml}$. Konsentrasi ekstrak sirih dalam setiap kemasan botol adalah $80 \%$. Konsentrasi ini lebih tinggi dibandingkan hasil penelitian Sari dan Isadiartuti (2006) yang menyatakan bahwa aktivitas antiseptic sediaan gel hand sanitizer dengan kadar ekstrak daun sirih $15 \%$ tidak berbeda bermakna dengan sediaan etanol sedangkan sediaan dengan kadar ekstrak 20\% dan 25\% mempunyai aktivitas yang sama dengan sediaan triclosan. Konsentrasi ekstrak sirih yang tinggi diharapkan lebih efektif dalam membunuh bakteri pathogen. Campuran kemudian diaduk secara manual hingga homogen membentuk larutan berwarna merah kecoklatan. Sebelum di kemas dalam botol, ke dalam hand sanitizer ditambahkan parfum untuk memberikan aroma wangi pada produk tersebiut. Secara keseluruhan proses raw material menjadi produk hand sanitizer ditunjukkan pada Gambar 3.1 berikut: 


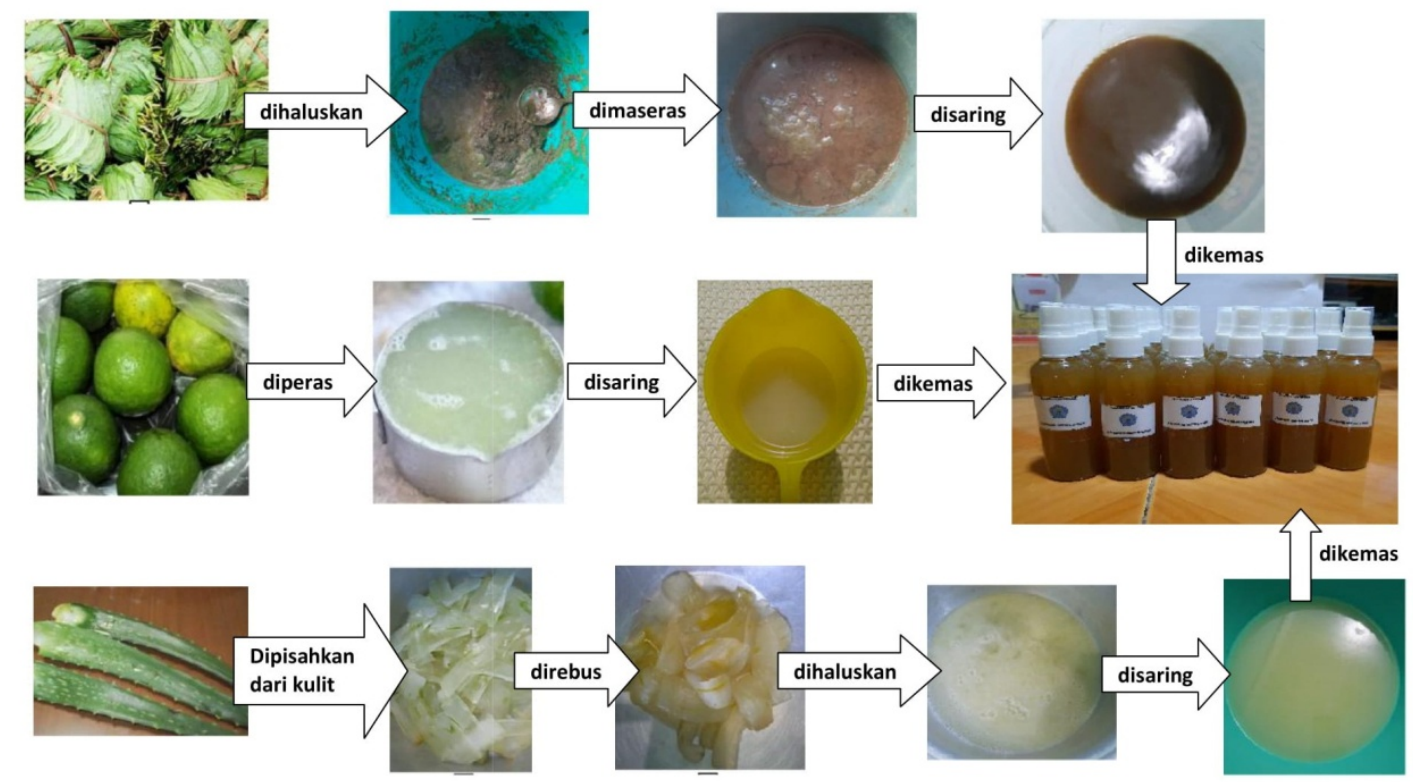

Gambar 3.1. Proses Pembuatan dan Pengemasan Hand sanitizer Alami.

\section{b. Edukasi dan Pembagian Hand sanitizer}

Edukasi dan pembagian hand sanitizer dilaksanakan di Desa Haulasi, Kecamatan Miomaffo Barat, Kabupaten Timor Tengah Utara, Provinsi Nusa Tenggara Timur. Edukasi dilakukan person to person melalui kunjungan rumah ke rumah oleh 2-4 partisipan (anggota tim pengabdian) untuk menghindari kerumunan warga. Proses edukasi dan pembagian hand sanitizer kepada masyarakat Desa Haulasi oleh tim pengabdian kepada masayarakat, disajikan pada Gambar 3.2 berikut.

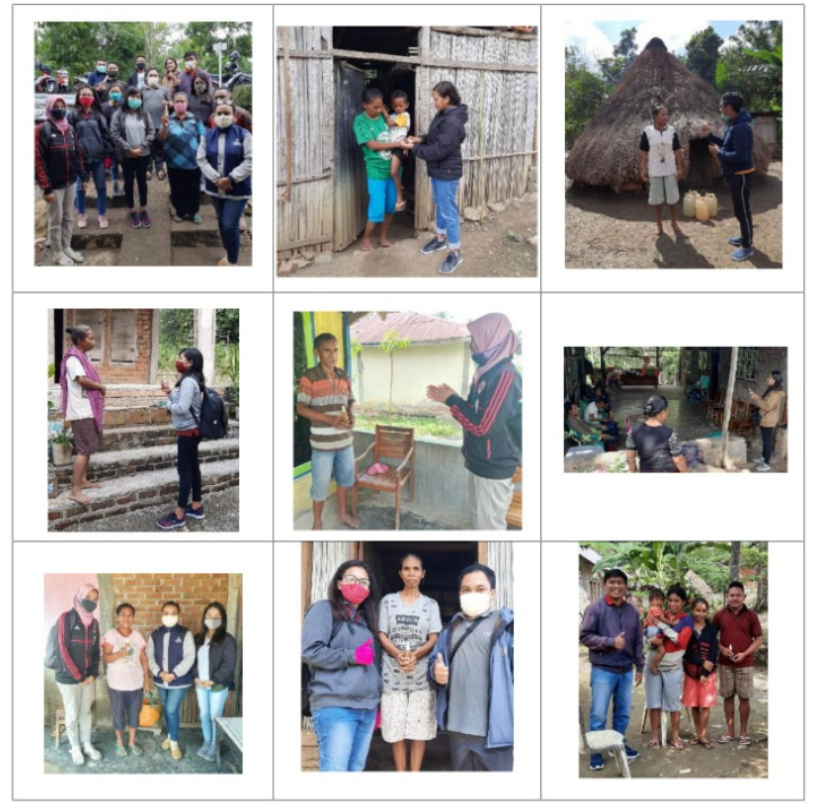

Gambar 3.2. Proses Edukasi kepada masyarakat Desa Haulasi 
Desa Haulasi terdiri atas 3 Dusun dengan jumlah Kepala Keluarga sebanyak 249. Oleh karena itu pembagian hand sanitizer tidak dilakukan secara menyeluruh kepada semua Kepala Keluarga mengingat keterbatasan jumlah produk. Oleh karenanya pembagian dilakukan secara random dengan mempertimbangkan layak tidaknya kepala keluarga dijadikan sebagai penerima melalui observasi langsung oleh masing-masing partisipan di lokasi kegiatan. Secara keseluruhan masyarakat Desa Haulasi memberikan respon yang baik terhadap kegiatan ini. Proses pembagian hand sanitizer kepada masyarakat Desa Haulasi oleh tim pengabdian kepada masayarakat, disajikan pada Gambar 3.3 berikut.

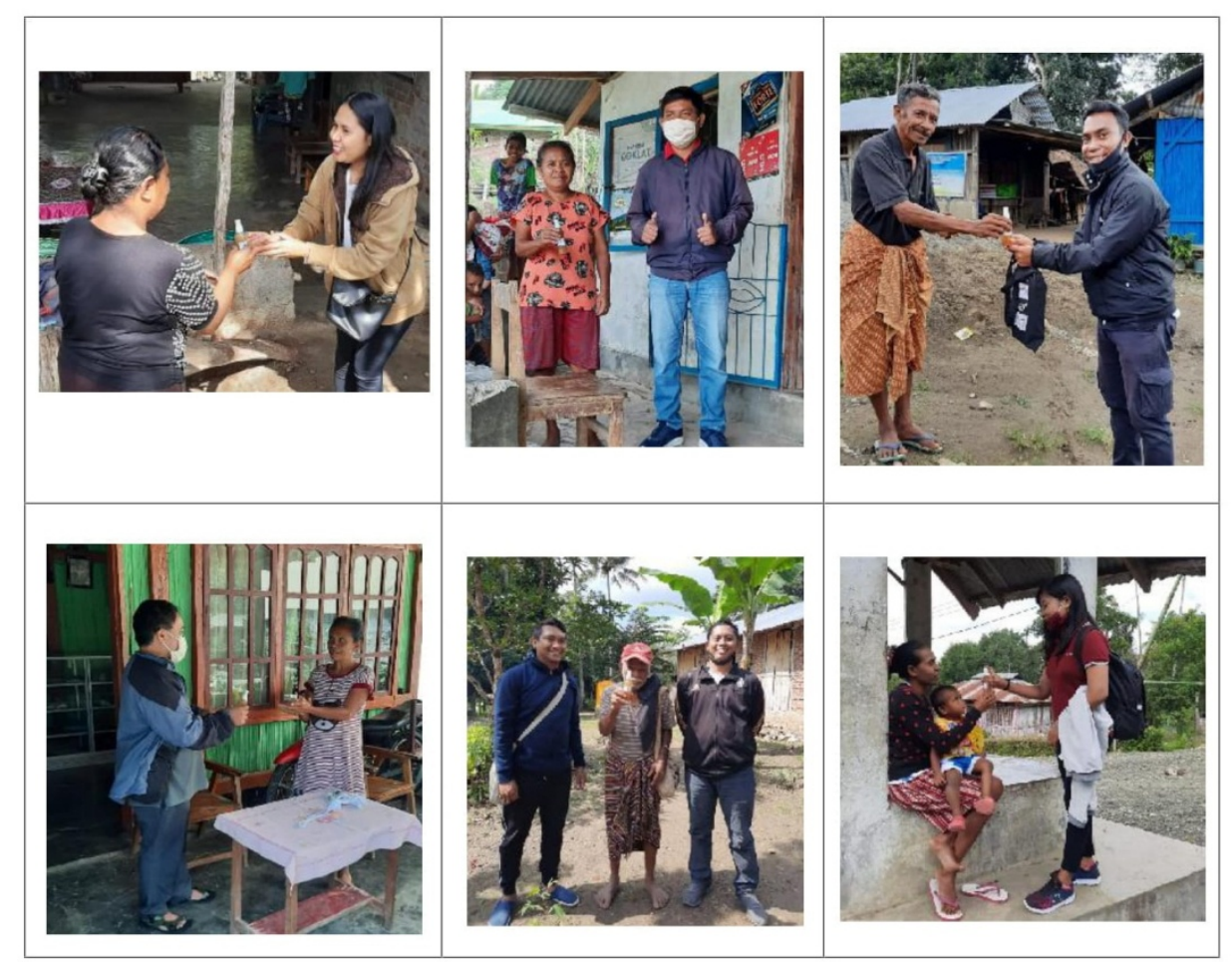

Gambar 3.2. Proses Pembagian Hand sanitizer kepada masyarakat Desa Haulasi

\section{KESIMPULAN}

Berdasarkan hasil dan pembahasan dapat disimpulkan bahwa:

a. Masyarakat menjadi tahu tentang pembuatan alternative bahan antiseptic alami sebagai salah satu media pencegah Covid-19

b. Masyarakat memperoleh produk contoh yang dapat meningkatkan minat mereka dalam menghasilkan produk serupa untuk menjaga kebersihan.

\section{UCAPAN TERIMAKASIH}

Terimakasih kepada pihak Fakultas Pertanian, Fakultas Ilmu Pendidikan dan Lembaga Penelitian dan Pengabdian kepada Masyarakat (LPPM) Universitas Timor yang telah mendukung kami selama proses persiapan hingga pelaksanaan pengabdian. 


\section{DAFTAR PUSTAKA}

Boangmanalu R. dan Zuhrotun, A. (2018). Review Artikel: Potensi Khasiat Obat Tanaman Marga Piper: Piper nigrum L., Piper retrofractum Vahl., Piper betle Linn., Piper cubeba L. dan Piper crocatum Ruiz \& Pav. Farmaka Suplemen Volume 16 (3): 204.

Bustanussalam, Apriasi, D., Suhardi, E., dan Jaenudin, D.(2015). Efektivitas Antibakteri Ekstrak Daun Sirih (Piper Betle Linn.) Terhadap Staphylococcus Aureus ATCC 25923. Fitofarmaka, Vol.5, No.2.

Chakraborty, D. dan Shah, B. (2011). Antimicrobial, Anti-Oxidative And Anti-Hemolytic Activity Of Piper Betel Leaf Extracts. International Journal of Pharmacy and Pharmaceutical Sciences. Vol 3, Suppl 3.

Kaveti, B., Tan, L., Sarnnia, Kuan, T. dan Baig, M. (2011). Antibacterial Activity Of Piper Betel Leaves. International Journal of Pharmacy Teaching \& Practices. Vol.2, Issue 3 (129-132).

Pradhan dan Biswasroy, P. (2013). Golden Heart of the Nature: Piper betle L. Journal of Pharmacognosy and Phytochemistry 1(6):147-167.

Pratiwi, N. dan Muderawan, I. (2016). Analisis Kandungan Kimia Ekstrak Daun Sirih Hijau (Piper Betle) dengan GC-MS. Prosiding Seminar Nasional MIPA 2016. FMIPA Undiksha.

Sari, R., \& Isadiartuti, D. (2006). Studi Efektivitas Sediaan Gel Antiseptik Tangan Ekstrak Daun Sirih (Piper betle Linn.). Majalah Farmasi Indonesia, 17(4):163-169.

Sarjani, S., Mawardi, Pandia, E. \& Wulandari, D. (2017). Identifikasi Morfologi dan Anatomi Tipe Stomata Famili Piperaceae di Kota Langsa. Jurnal IPA dan Pembelajaran IPA (JIPI), 1(2): 182191.

Sripradha, S. (2011). Betel Leaf - The Green Gold. Journal of Pharmaceutical Science \& Research. Vol. 6(1): $36-37$.

Tjitrosoepomo, G. (2004). Taksonomi Tumbuhan (Spermatophyta). Yogyakarta: Gadjah Mada University Press. 